\title{
Scorpion venoms: taking the sting out of lung disease
}

\author{
D F Rogers
}

\begin{abstract}
Scorpion venoms contain specific toxins which block large conductance calciumactivated potassium $\left(\mathrm{BK}_{\mathrm{Ca}}\right)$ channels. Use of these toxins has shown that a significant proportion of the action of bronchodilators such as $\beta$-agonists, theophylline, and nitric oxide occurs as a result of the opening of $\mathrm{BK}_{\mathrm{Ca}}$ channels. Similarly, these toxins have shown that inhibitors of airway neurotransmission also operate via $\mathbf{B K}_{\mathrm{Ca}}$ channels. Drugs that open $\mathrm{BK}_{\mathrm{Ca}}$ channels may be alternative bronchodilators (possibly "airway selective" and with fewer side effects) as well as inhibitors of pathophysiological neurogenic influences in asthma, chronic coughing and sneezing, and chronic bronchitis.

(Thorax 1996;51:546-548)
\end{abstract}

Keywords: $\mathrm{K}^{+}$channels, asthma, $\beta$-agonist, bronchodilator drugs, nerve.

The scorpion's name is Stingaling, a most repulsive, ugly thing, and I would never recommend that you should treat him as a friend.

The Scorpion (Roald Dahl)

Scorpions may be abhorrent, but their venoms could redefine drug treatment of several airway diseases. Certain toxins in the venom of scorpions selectively occlude large conductance calcium-activated potassium $\left(\mathrm{BK}_{\mathrm{Ca}}\right.$ or maxi-K) channels in the cell membrane. These channels are involved in the control of muscle tone and neurotransmission, and opening them causes membrane hyperpolarisation with consequent relaxation of muscle and inhibition of neurotransmitter release. Closure of the channels takes off the "brakes" and leads to loss of muscle relaxation (or induction of contraction) and loss of neural inhibition. These processes have relevance to asthma by their involvement in bronchodilation and bronchoconstriction, and to additional airway diseases by involvement in neurogenic inflammation of the airways. The use of scorpion venoms to block $\mathrm{BK}_{\mathrm{Ca}}$ channels has increased our understanding of how bronchodilator drugs work, and has indicated novel approaches to drug treatment of airways disease.

\section{Scientific basis \\ $\mathrm{BK}_{\mathrm{Ca}}$ CHANNELS AND SCORPION VENOMS}

The $\mathrm{BK}_{\mathrm{Ca}}$ channel is characterised electrophysiologically by high conductance (100-300 $\mathrm{pS})$, high selectivity for potassium $\left(\mathrm{K}^{+}\right)$over other ions, activation by depolarising voltage and intracellular $\mathrm{Ca}^{2+}$ concentration, and has been visualised as a wide-mouthed whirlpool. Toxins from certain scorpions occlude the mouth of $\mathrm{BK}_{\mathrm{Ca}}$ channels and block $\mathrm{K}^{+}$flux. ${ }^{1}$ One such toxin was isolated from the venom of the five-keeled gold scorpion (Leiurus quinquestriatus) and was named charybdotoxin after Charybdis, a female sea monster in Greek mythology who created whirlpools by sucking in water. A more selective $\mathrm{BK}_{\mathrm{Ca}}$ channel blocker was derived from the Indian scorpion Mesobuthus tamulus and was named iberiotoxin to acknowledge the contribution of Spanish scientists to its discovery. Charybdotoxin and iberiotoxin have been used to investigate the role of $\mathrm{BK}_{\mathrm{Ca}}$ channels in the control of airway smooth muscle tone and neurotransmission: reversal by the toxin of bronchodilation or neural inhibition indicates the involvement of endogenous $\mathrm{BK}_{\mathrm{Ca}}$ channels in the initial response.

\section{BRONCHODILATION}

$\beta_{2}$-Adrenoceptor agonist drugs induce bronchodilation. Biochemical - and electrophysiological studies have shown that $\beta$-agonists open $\mathrm{BK}_{\mathrm{Ca}}$ channels on airway smooth muscle cells via intracellular signal transduction mechanisms which are dependent and independent of cyclic $3^{\prime}, 5^{\prime}$-adenosine monophosphate (cAMP) (figure). ${ }^{2}$ Both mechanisms are initiated by $\beta$-agonist occupation of $\beta_{2}$-adrenoceptors on the airway smooth muscle cells, leading to activation of a stimulatory guanine nucleotide binding protein $\left(\mathrm{G}_{\mathrm{s}}\right)$. In the cAMPdependent pathway $G_{s}$ triggers an enzyme cascade which leads to the phosphorylation of a number of cellular substrates involved with relaxation (figure). Bronchodilation induced by nitric oxide (NO) is the result of a similar enzymatic cascade. One of the phosphorylation events is opening of $\mathrm{BK}_{\mathrm{Ca}}$ channels. In the cAMP-independent pathway the $\mathrm{BK}_{\mathrm{Ca}}$ channel is opened directly by coupling to $\mathrm{G}_{\mathrm{s}}{ }^{3}$
Thoracic Medicine

Lung Institute

(Imperial College),

London SW3 6LY, UK

D F Rogers 


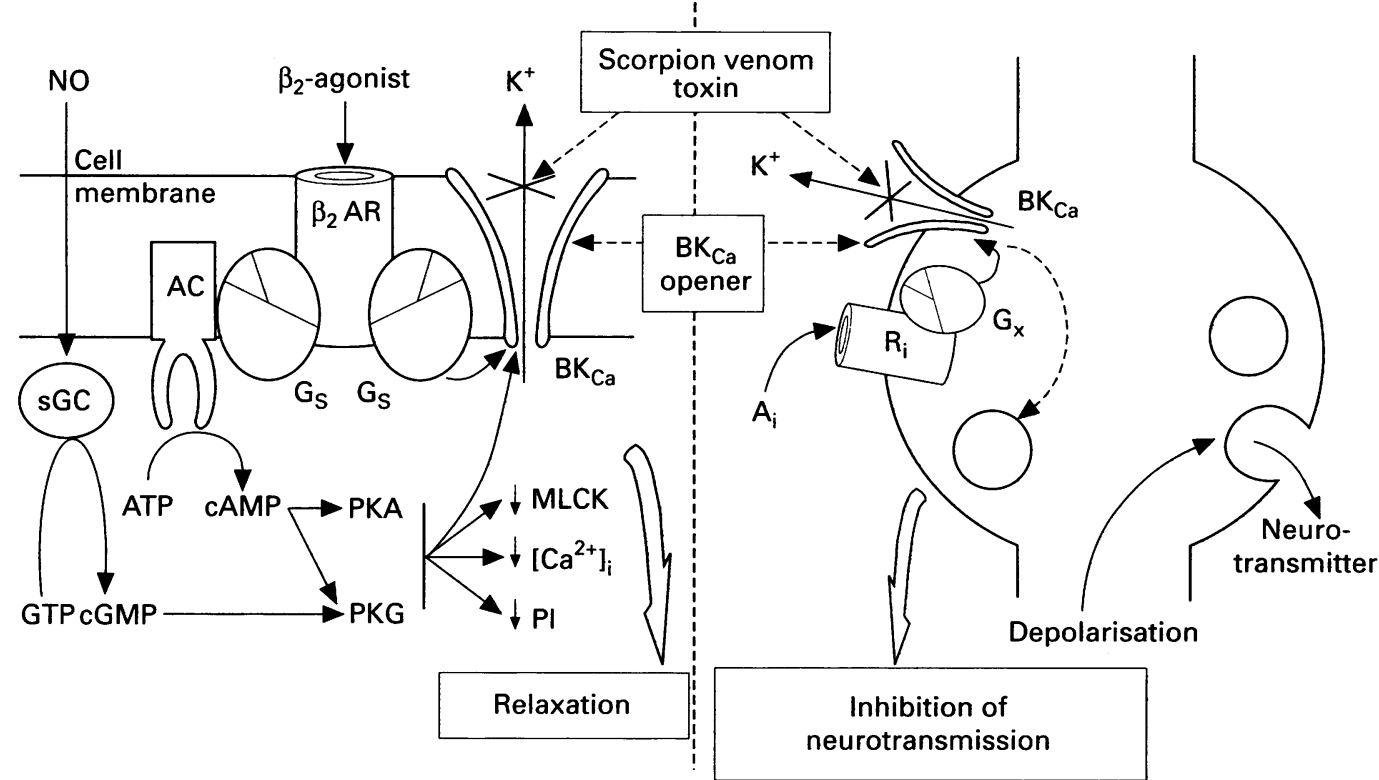

Use of scorpion venom toxins to investigate bronchodilator drug action and neural inhibition. Left panel: Interaction of $\beta_{2}$-agonist drug (for example, salbutamol) with $\beta_{2}$-adrenoceptors $\left(\beta_{2} A R\right)$ activates a stimulatory guanine nucleotide binding protein $\left(G_{s}\right)$ which initiates adenylyl cyclase $(A C)$ to convert adenosine triphosphate $(A T P)$ to $c A M P$. Cyclic $A M P$ activates protein kinase $A(P K A)$ and PKG which phosphorylate cellular substrates involved with relaxation. $A$ similar enzymatic cascade is seen after activation of guanylyl cyclase by, for example, nitric oxide (NO).

Phosphorylation processes relevant to relaxation are inhibition of myosin light chain kinase (MLCK), decreased intracellular calcium, inhibition of phosphoinositide hydrolysis (PI), and opening of large conductance calcium-activated potassium $\left(B K_{C a}\right)$ channels. $B K_{C a}$ channels may also be coupled directly to $G_{s}$. Right panel: Depolarisation of nerves induces neurotransmitter release and neurotransmission. Interaction of agonists which inhibit neurotransmission $\left(A_{i}\right.$ e.g. morphine) with specific receptors ( $R_{i}$, e.g. $\mu$-opioid) inhibits neurotransmitter release via opening of $B K_{C a}$ channels leading to membrane hyperpolarisation. Neuronal $B K_{C a}$ channels appear to be coupled directly to a $G$ protein, as yet not specifically defined $\left(G_{x}\right.$, possibly $\left.G_{o l}\right) . B K_{C a}$ channel-selective scorpion venom toxins inhibit $\beta$-agonist induced relaxation of airway smooth muscle and neurogenic responses, demonstrating the involvement of these channels. Drugs which open $B K_{\mathrm{Ca}}$ channels may be novel bronchodilators and inhibitors of airway neurotransmission in pathophysiological conditions of the airways.

In functional studies in vitro, iberiotoxin has been shown to inhibit relaxation of guinea pig tracheal smooth muscle induced by the $\beta$-agonists isoprenaline and salbutamol and by the NO donor sodium nitroprusside. ${ }^{4}$ Charybdotoxin reverses relaxation induced by isoprenaline and theophylline in human bronchi. ${ }^{5}$ These observations indicate that $\mathrm{BK}_{\mathrm{Ca}}$ channels are involved in smooth muscle relaxation induced by different bronchodilator drugs.

\section{INHIBITION OF NEUROTRANSMISSION}

Activation of at least eight receptor types including $\mu$-opioid, $\alpha_{2}$-adrenergic, and neuropeptide $\mathrm{Y}$ - inhibits bronchoconstriction and airway mucus secretion and plasma exudation induced by neural stimulation. Charybdotoxin blocks the inhibitory effects of these receptors on cholinergic nerves and capsaicin-sensitive sensory nerves in guinea pig and human airways in vitro, ${ }^{67}$ which indicates that $\mathrm{BK}_{\mathrm{Ca}}$ channels are a common endogenous mechanism for the regulation of nerve activity in the airways.

\section{Therapeutic potential}

Inhaled $\beta$-agonists are effective bronchodilators and are vitally important in the management of asthma. However, because of concerns over the safety of $\beta$-agonists and because of the search for new drugs by pharmaceutical companies, novel bronchodilators are being sought.
Airway nerves may contribute to the pathophysiology of a number of bronchial diseases - for example, sensory nerves may be involved in asthma, in chronic coughing and sneezing ${ }^{8}$ and, perhaps, in chronic bronchitis. In asthma there is also dysfunction of cholinergic nerves which could exaggerate cholinergic bronchoconstriction and mucus secretion. ${ }^{10}$

Thus, drugs which open $\mathrm{BK}_{\mathrm{Ca}}$ channels may be useful both as novel bronchodilators (possibly with reduced side effects) and as inhibitors of nerve dysfunction in asthma, chronic coughing and sneezing, and chronic bronchitis. To avoid cardiovascular problems associated with non-selective opening of $\mathrm{K}^{+}$channels - for example, postural hypotension - "airway selective" $\mathrm{K}^{+}$channel activators are being sought. A number of drugs which will open $\mathrm{BK}_{\mathrm{Ca}}$ channels are becoming available of which one, NS 1619 , is highly selective for this channel in airway smooth muscle ${ }^{11}$ and inhibits neurogenic airway mucus secretion. ${ }^{12}$

\section{Conclusions}

Scorpion venoms have proved invaluable pharmacological research tools in evaluating the role of $\mathrm{BK}_{\mathrm{Ca}}$ channels in the control of airway smooth muscle tone, in the action of bronchodilator drugs, and in regulation of neurotransmission. As a consequence, new $\mathbf{B K}_{\mathrm{Ca}}$ channel activator drugs are being developed 
which may be of value in the treatment of a number of different airway diseases.

The author thanks the National Asthma Campaign and Syntex Research for support, Paul Hillyard (Natural History Museum, London) for the scorpion names, Maria Garcia (Merck Institute for Therapeutic Research, New Jersey) for the derivations of the toxin names, and Chris Seagrave for the scepticism which prompted writing of the article.

1 Garcia ML, Galvez A, Garcia-Calvo M, King VF, Vasquez $\mathrm{J}$, Kaczorowski GJ. Use of toxins to study potassium J, Kaczorowski GJ. Use of toxins to study
channels. $尹$ Bioenerg Biomembr 1991;23:615-46.

2 Torphy TJ. $\beta$-Adrenoceptors, cAMP and airway smooth Torphy TJ. $\beta$-Adrenoceptors, CAMP and airway smooth
muscle: challenges to the dogma. Trends Pharmacol Sci 1994;15:370-4

3 Kume H, Hall IP, Washabau RJ, Takagi K, Kotlikoff MI. $\beta$-Adrenergic agonists regulate $K_{C a}$ channels in airway smooth muscle by cAMP-dependent and independent mechanisms. F Clin Invest 1994;93:371-9.

4 Jones TR, Charette L, Garcia ML, Kaczorowski GJ. Interaction of iberiotoxin with $\beta$-adrenoceptor agonists and sodium nitroprusside on guinea pig trachea. $\mathcal{F} A$ ppl Physiol 1993;74:1879-84.
5 Miura M, Belvisi MG, Stretton CD, Yacoub MH, Barnes PJ. Role of potassium channels in bronchodilator responses in human airways. Am Rev Respir Dis 1992;146:132-6.

6 Miura M, Belvisi MG, Stretton CD, Yacoub MH, Barnes PJ. Role of $\mathrm{K}^{+}$channels in the modulation of cholinergic neural responses in guinea-pigs and human airways. $f$ Physiol 1992;455:1-15.

7 Stretton CD, Miura M, Belvisi MG, Barnes PJ. Calciumactivated potassium channels mediate prejunctional inhibition of peripheral sensory nerves. Proc Natl Acad Sci USA 1992;89:1325-9.

8 Barnes PJ. Asthma as an axon reflex. Lancet 1986;i:242-5.

9 Karlsson J-A. A role for capsaicin-sensitive, tachykinin containing nerves in chronic coughing and sneezing but not in asthma: a hypothesis. Thorax 1993;48:396-400.

10 Barnes PJ. Muscarinic receptors in the airways: recent developments. $\mathcal{f}$ Appl Physiol 1990;68:1777-85.

11 Macmillan S, Sheridan RD, Chilvers ER, Patmore L. A Macmillan S, Sheridan RD, Chilvers ER, Patmore L. A
comparison of the effects of SCA40, NS 004 and NS 1619 on large conductance $\mathrm{Ca}^{2+}$-activated $\mathrm{K}^{+}$channels in bovine tracheal smooth muscle cells in culture. $\mathrm{Br} \mathcal{F}$ Pharmacol 1995;116:1656-60.

12 Ramnarine SI, Khawaja AM, Bryce P, Hicks PE, Barnes PJ, Rogers DF. Effects of potassium channel openers on neurogenic airway mucus secretion in the ferret. $A m$ Respir Crit Care Med 1995;151:A820. 